\title{
Monoacetylcurcumin strongly regulates inflammatory responses through inhibition of $\mathrm{NF}-\mathrm{kB}$ activation
}

\author{
MASAYUKI NISHIDA ${ }^{1,3}$, SHIN NISHIUMI ${ }^{1,2}$, YOSHIYUKI MIZUSHINA ${ }^{3,4}$, YOSHIMI FUJISHIMA ${ }^{1}$, \\ KOJI YAMAMOTO ${ }^{1}$, ATSUHIRO MASUDA ${ }^{1,5}$, SHIGETO MIZUNO ${ }^{5}$, TSUYOSHI FUJITA ${ }^{1}$, YOSHINORI MORITA ${ }^{1}$, \\ HIROMU KUTSUMI $^{1}$, HIROMI YOSHIDA ${ }^{3,4}$, TAKESHI AZUMA $^{1}$ and MASARU YOSHIDA ${ }^{1,2}$ \\ ${ }^{1}$ Division of Gastroenterology, Department of Internal Medicine, ${ }^{2}$ The Integrated Center for Mass Spectrometry, \\ Graduate School of Medicine, Kobe University, 7-5-1 Chu-o-ku, Kusunoki-Cho, Kobe, Hyogo 650-0017; \\ ${ }^{3}$ Laboratory of Food and Nutritional Sciences, Department of Nutritional Science, ${ }^{4}$ Cooperative Research Center \\ of Life Sciences, Kobe-Gakuin University, Nishi-ku, Kobe, Hyogo 651-2180; ${ }^{5}$ Medical Pharmaceutics, \\ Kobe Pharmaceutical University, Higashinada-ku, Kobe, Hyogo 658-8558, Japan
}

Received November 26, 2009; Accepted January 12, 2010

DOI: 10.3892/ijmm_00000402

\begin{abstract}
Curcumin, a component of turmeric (Curcuma longa), is known to exert a variety of biological functions including anti-inflammatory activity. We examined the inhibitory effects of chemically synthesized derivatives of curcumin against inflammatory responses and compared them with those of curcumin, in order to find derivatives with stronger effects than curcumin. In a cell culture system using the mouse macrophage cell line RAW264.7, monoacetylcurcumin strongly inhibited $\mathrm{I} \kappa \mathrm{B}$ phosphorylation, nuclear factor (NF) $-\kappa B$ activation and tumor necrosis factor (TNF) $-\alpha$ production induced by lipopolysaccharide (LPS). In addition, oral administration of monoacetylcurcumin to mice led to greater suppression of TNF- $\alpha$ production after LPS stimulation than the administration of curcumin or tetrahydrocurcumin in vivo. Monoacetylcurcumin also inhibited the LPS-induced $\mathrm{NF}-\kappa \mathrm{B}$ activation in the liver. Collectively, monoacetylcurcumin is a potential chemopreventive agent for treating inflammatory responses more effectively than curcumin.
\end{abstract}

\section{Introduction}

Curcumin (diferuloylmethane; 1,7-bis(4-hydroxy-3-methoxyphenyl)-1-6-heptadine-3,5-dione) is one of the biologically

Correspondence to: Dr Masaru Yoshida, Division of Gastroenterology, Department of Internal Medicine, Graduate School of Medicine, Kobe University, 7-5-1 Chu-o-ku, KusunokiCho, Kobe, Hyogo 650-0017, Japan

E-mail:myoshida@med.kobe-u.ac.jp

Abbreviations: LPS, lipopolysaccharide; TNF- $\alpha$, tumor necrosis factor- $\alpha$; ROS, reactive oxygen species

Key words: curcumin, monoacetylcurcumin, nuclear factor-кВ, tumor necrosis factor- $\alpha$, anti-inflammation active compounds found in the Indian spice turmeric (Curcuma longa). It belongs to a family called curcuminoids and usually comprises approximately $3 \%$ of turmeric powder, which is commonly used as a preservative in foods and a yellow pigment in textiles. Presently, curcumin is well known as an anti-oxidant agent, and the pharmacological potential of curcumin is under investigation (1).

Previous studies have found that some naturally occurring compounds including curcumin are potential therapeutics for treating nuclear factor (NF)- $\mathrm{BB}$-dependent inflammatory responses (2). The activation of $\mathrm{NF}-\kappa \mathrm{B}$ is the rate-limiting step for various inflammatory responses (3). The five members of the mammalian NF-кB family, namely p65 (RelA), RelB, c-Rel, p50/p105 (NF-кB1) and p52/p100 (NF-кB2), exist in unstimulated cells as homodimers or heterodimers bound to

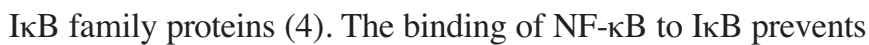
$\mathrm{NF}-\kappa \mathrm{B}$ from translocating to the nucleus, thereby maintaining $\mathrm{NF}-\kappa \mathrm{B}$ in an inactive state. $\mathrm{NF}-\kappa \mathrm{B}$ proteins are characterized by the presence of a conserved 300-amino acid Rel homology domain located in the $\mathrm{N}$ terminus of the protein, and the domain is responsible for dimerization with $\mathrm{NF}-\mathrm{\kappa B}$, interaction with IкB, and binding to DNA (4). The translocated $\mathrm{NF}-\kappa \mathrm{Bs}$ work as transcription factors and regulate the expression of various genes that encode proinflammatory cytokines such as tumor necrosis factor (TNF)- $\alpha$ and IL-12, which have been shown to play important roles in sustained inflammatory responses (5-7). In fact, it was found that curcumin ameliorates trinitrobenzene sulfonic acid (TNBS)induced colitis in mice (8), which is a mouse model of inflammatory bowel disease, and curcumin suppressed the $\mathrm{CD}^{+} \mathrm{T}$-cell infiltration and $\mathrm{NF}-\kappa \mathrm{B}$ activation in colonic mucosa (8).

After absorption into the human body, curcumin undergoes metabolic conversion to its sulfate, glucuronide, and sulfatedglucuronide conjugate (9). In the liver, curcumin is converted to hexahydrocurcumin, tetrahydrocurcumin and hexahydrocurcuminol through endogenous reductase systems (10). Tetrahydrocurcumin has been demonstrated to be the major curcumin metabolite in vivo (11) and is an active metabolite 
of curcumin. Tetrahydrocurcumin has also been widely studied due to its potential anti-oxidant, anti-inflammatory and anticarcinogenic activities and its ability to modulate multidrug-resistant proteins (12-14). Therefore, there is a possibility that tetrahydrocurcumin plays a crucial role in the biological effects of curcumin in vivo. Thus, curcumin and tetrahydrocurcumin are potential anti-inflammatory agents.

Various curcumin derivatives, such as demethoxycurcumin, bisdemethoxycurcumin, turmerones and monoacetylcurcumin, have been chemically synthesized in the hope of discovering derivatives exhibiting a higher biological activity than curcumin (15). In our previous study, we found that curcumin selectively inhibits the activity of DNA polymerase $\lambda$ in the 10 species of mammalian DNA polymerases tested (16). We also investigated the inhibition of DNA polymerase $\lambda$ by 13 chemically synthesized derivatives of curcumin and found that monoacetylcurcumin was the strongest inhibitor of DNA polymerase $\lambda$ among the curcumin derivatives and curcumin (17), suggesting that monoacetylcurcumin is a potent candidate for functional compounds. In this study, we investigated the inhibitory effects of monoacetylcurcumin on inflammatory responses in comparison with those of curcumin and tetrahydrocurcumin in vitro and in vivo. Monoacetylcurcumin suppressed $\mathrm{NF}-\kappa \mathrm{B}$ activation induced by lipopolysaccharide (LPS) and TNF- $\alpha$ in mouse macrophage RAW264.7 and human embryonic kidney HEK293 cells, respectively. Moreover, we also demonstrated that monoacetylcurcumin exerts inhibitory effects against TNF- $\alpha$ production and NF- $\kappa \mathrm{B}$ activation in an LPS-induced acute inflammation animal model.

\section{Materials and methods}

Chemicals. Curcumin (Fig. 1A) and LPS were purchased from Sigma (St. Louis, MO). Monoacetylcurcumin (Fig. 1B) and tetrahydrocurcumin (Fig. 1C) were chemically synthesized from curcumin as described in reports by Takeuchi et al (17) and Sugiyama et al (18), respectively. The purity of the synthesized tetrahydrocurcumin and monoacetylcurcumin was $>98 \%$ (data not shown). For Western blot analysis, anti$\mathrm{NF}-\kappa \mathrm{B}$ p65 antibody and horseradish peroxidase-conjugated anti-rabbit IgG antibody were obtained from Santa Cruz Biotechnology (Santa Cruz, CA) and Thermo Scientific (Kanagawa, Japan), respectively.

Cell culture. The human embryonic kidney cell line HEK293 and the murine macrophage cell line RAW264.7 were maintained in DMEM supplemented with $4.5 \mathrm{~g}$ glucose per liter plus $10 \%$ fetal calf serum, $5 \mathrm{mM}$ L-glutamine, 50 units $/ \mathrm{ml}$ penicillin and 50 units $/ \mathrm{ml}$ streptomycin and were cultured in a humidified incubator with an atmosphere of $95 \%$ air and $5 \% \mathrm{CO}_{2}$ at $37^{\circ} \mathrm{C}$.

Measurement of the TNF- $\alpha$ secreted from RAW264.7 cells. RAW264.7 cells were seeded on a 12-well plate at $1 \times 10^{5}$ cells/ well and incubated for $24 \mathrm{~h}$. The cells were pretreated with 10 or $50 \mu \mathrm{M}$ curcumin, tetrahydrocurcumin or monoacetylcurcumin for $30 \mathrm{~min}$ and then stimulated with $100 \mathrm{ng} / \mathrm{ml}$ LPS. After $24 \mathrm{~h}$, the cell culture medium was collected to measure the TNF- $\alpha$ level. The concentration of TNF- $\alpha$ in the<smiles>COc1cc(/C=C(O)/C=C/C(=O)/C=C/c2ccc(O)c(OC)c2)ccc1O</smiles>

B<smiles>COc1cc(/C=C/C(O)=C/C(=O)/C=C/c2ccc(OC(C)=O)c(OC)c2)ccc1O</smiles>

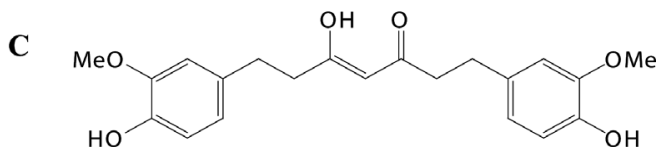

Figure 1. The chemical structures of curcumin and curcumin derivatives. (A) Curcumin, (B) monoacetylcurcumin and (C) tetrahydrocurcumin.

culture medium was quantified using a commercially available ELISA development system (Bay Bioscience Co., Ltd., Kobe, Japan) according to the manufacturer's protocol.

Cell treatment and preparation of nuclear and whole cellular proteins. RAW264.7 and HEK293 cells were pretreated with $50 \mu \mathrm{M}$ curcumin, tetrahydrocurcumin or monoacetylcurcumin for $30 \mathrm{~min}$ followed by treatment with $100 \mathrm{ng} / \mathrm{ml}$ LPS for RAW264.7 cells and $20 \mathrm{ng} / \mathrm{ml} \mathrm{TNF-} \alpha$ for HEK293 cells. After $30 \mathrm{~min}$, the nuclear proteins and whole cell lysates were isolated from RAW264.7 cells and/or HEK293 cells as described in a previous report (19). The protein concentrations of the nuclear proteins and whole cell lysates were measured using BCA $^{\mathrm{TM}}$ Protein Assay Kit (Pierce, Rockford, IL) according to the manufacturer's protocol. Briefly, $25 \mu 1$ of each sample or $2 \mathrm{mg} / \mathrm{ml}$ BSA solution as a standard was added to a 96-well microplate well, and then $200 \mu 1$ of BCA Working Reagent was added to each well. This microplate was incubated at $37^{\circ} \mathrm{C}$ for $30 \mathrm{~min}$, and the protein concentration was determined by measurement of an absorbance at $575 \mathrm{~nm}$. The nuclear proteins and whole cell lysates were subjected to Western blotting to evaluate the nuclear translocation of $\mathrm{NF}-\kappa \mathrm{B}$ and phosphorylation of ІкB.

Western blotting. The nuclear proteins (30-50 $\mu \mathrm{g}$ proteins) and whole cell lysates (50 $\mu \mathrm{g}$ proteins) were boiled in a quarter volume of sample buffer (1 M Tris-HCl, $\mathrm{pH} 7.5$, $640 \mathrm{mM}$ 2-mercaptoethanol, $0.2 \%$ bromphenol blue, $4 \%$ SDS and $20 \%$ glycerol) and then separated on $10 \%$ SDSpolyacrylamide gels. The proteins in the gels were transferred to a PVDF membrane. The membrane was blocked with $1 \%$ skimmed milk for $\mathrm{NF}-\kappa \mathrm{B}$ p65 or 5\% bovine serum albumin for phosphorylated IкB in TBS-T (10 mM Tris- $\mathrm{HCl}, 100 \mathrm{mM}$ $\mathrm{NaCl}$ and $0.5 \%$ Tween-20) and probed with anti-NF-кB p65 antibody (1:1000) or anti-phospho-IкB antibody (1:1000) 
before being reacted with the horseradish peroxidaseconjugated secondary antibody. The protein-antibody complex was detected using ChemiLumiONE (Nacalai Tesque, Japan) and an Image Reader (LAS-3000 Imaging System, Fuji Photo Film). The intensity of each band was analyzed using ImageJ, which was developed at the National Institutes of Health.

Determination of intracellular ROS. Measurement of intracellular reactive oxygen species (ROS) was performed according to the method of a previous report (20). ROS generation in the cells was assessed using the probe 2,7dichlorofluorescein $(\mathrm{DCF})$. The cells are treated with the membrane-permeable diaetate form, 2',7'-dichlorodihydrofluorescin diacetate (DCFH-DA), and DCFH-DA is converted to the reduced form of DCF (DCFH) by esterase in the cells. ROS in the cells oxidize DCFH, yielding the fluorescent product DCF. Briefly, HEK293 cells were cultured in a 96-well plate for $24 \mathrm{~h}$ and pretreated with $50 \mu \mathrm{M}$ curcumin, tetrahydrocurcumin or monoacetylcurcumin. After $30 \mathrm{~min}$, the cells were treated with $4 \mu \mathrm{M}$ DCFH-DA and $50 \mathrm{ng} / \mathrm{ml} \mathrm{TNF}-\alpha$ for $30 \mathrm{~min}$ in the presence or absence of curcumin, tetrahydrocurcumin or monoacetylcurcumin. The fluorescent intensity of DCF was analyzed with a fluorescence reader (Thermo Scientific) using $485 \mathrm{~nm}$ excitation and $538 \mathrm{~nm}$ emission filters.

Animal experiment. All animal studies were performed according to the guidelines outlined in the "Care and Use of Laboratory Animals' of Kobe-Gakuin University. The animals were anesthetized with pentobarbital before undergoing cervical dislocation. Male 8-week-old C57BL/6 mice that had been bred in-house with free access to food and water were used for all experiments. All of the mice were maintained under a 12-h light/dark cycle and housed at a room temperature of $25^{\circ} \mathrm{C}$. The mice were orally administered $100 \mathrm{mg} / \mathrm{kg}$ body weight curcumin, tetrahydrocurcumin or monoacetylcurcumin dissolved in corn oil, respectively, or $200 \mu 1$ of corn oil as a vehicle control. After $2 \mathrm{~h}$, the mice were intraperitoneally injected with $250 \mu \mathrm{g} / \mathrm{kg}$ body weight (BW) LPS dissolved in PBS or $200 \mu 1$ of PBS as a vehicle control. After $1 \mathrm{~h}$, the mice were sacrificed, and their blood and liver were collected. The blood serum was separated by centrifugation at $15,000 \mathrm{x} \mathrm{g}$ for $10 \mathrm{~min}$ at $4^{\circ} \mathrm{C}$. The TNF- $\alpha$ level in the serum was measured using ELISA. Nuclear proteins in the liver were prepared according to the method of a previous report (21), and the protein concentration was measured by BCA assay. The nuclear proteins were subjected to Western blotting to evaluate the nuclear translocation of NF-кB.

Statistical analysis. All data are expressed as means \pm SE of at least three independent determinations for each experiment. Statistical significance was analyzed using the Student's t-test, and a level of probability of 0.05 was used as the criterion of significance.

\section{Results}

The inhibitory activity of curcumin and curcumin derivatives against inflammatory responses in cultured cells. First, the inhibitory activity of curcumin, tetrahydrocurcumin and monoacetylcurcumin against the LPS-induced TNF- $\alpha$ production in RAW264.7 cells was investigated to assess their anti-inflammatory activity (Fig. 2A). In RAW264.7 cells, cytotoxicity of curcumin, tetrahydrocurcumin and monoacetylcurcumin at $50 \mu \mathrm{M}$ was not observed (data not shown). We found that $50 \mu \mathrm{M}$ curcumin, tetrahydrocurcumin or monoacetylcurcumin significantly suppressed the $100 \mathrm{ng} /$ ml LPS-stimulated TNF- $\alpha$ production, and the order of inhibitory activity was monoacetylcurcumin $>$ curcumin $>>$ tetrahydrocurcumin. At $10 \mu \mathrm{M}$, the significant suppressive effects of tetrahydrocurcumin and monoacetylcurcumin on TNF- $\alpha$ production were confirmed, although tetrahydrocurcumin did not exhibit a dose-dependent effect. Curcumin at $10 \mu \mathrm{M}$ did not significantly inhibit the TNF- $\alpha$ production. The $\mathrm{IC}_{50}$ values of curcumin and monoacetylcurcumin were 29.8 and $23.4 \mu \mathrm{M}$, respectively; the $\mathrm{IC}_{50}$ value of tetrahydrocurcumin was not determined (Fig. $2 \mathrm{~B}$ ). NF- $\kappa \mathrm{B}$ is known to be the rate-controlling factor for inflammatory responses. Therefore, the inhibitory effects of curcumin, tetrahydrocurcumin and monoacetylcurcumin on the LPS-induced nuclear translocation of NF- $\mathrm{KB}$ were examined in RAW264.7 cells (Fig. 2C). Curcumin $(50 \mu \mathrm{M})$ and monoacetylcurcumin inhibited the $100 \mathrm{ng} / \mathrm{ml}$ stimulated $\mathrm{NF}-\kappa \mathrm{B}$ nuclear translocation, whereas tetrahydrocurcumin did not block the nuclear translocation. It was found that stimulation with LPS results in the activation of Toll-like receptor 4 and the downstream IкB kinases (IKKs), which in turn phosphorylate $\mathrm{I} \kappa \mathrm{B}$, the degradation of $\mathrm{I} \kappa \mathrm{B}$ and the translocation of NF- $\mathrm{NB}$ into the nucleus (22). Therefore, the suppressive effects of curcumin, tetrahydrocurcumin and monoacetylcurcumin on the LPS-induced phosphorylation of IкB were examined in RAW264.7 cells (Fig. 2C). In the Western blot analysis, it was revealed that $50 \mu \mathrm{M}$ curcumin and monoacetylcurcumin inhibited the LPS-induced phosphorylation of IкB (Fig. 2C). In contrast, tetrahydrocurcumin did not suppress IкB phosphorylation (Fig. 2C).

Next, the suppressive effects of curcumin, tetrahydrocurcumin and monoacetylcurcumin on the TNF- $\alpha$-evoked $\mathrm{NF}-\kappa \mathrm{B}$ nuclear translocation were investigated in HEK293 cells (Fig. 2C). Inhibition of $20 \mathrm{ng} / \mathrm{ml} \mathrm{TNF-} \alpha$-induced NF- $\mathrm{BB}$ nuclear translocation by $50 \mu \mathrm{M}$ curcumin or monoacetylcurcumin was observed, although $50 \mu \mathrm{M}$ tetrahydrocurcumin did not suppress the nuclear translocation. These results demonstrated that monoacetylcurcumin as well as curcumin suppress the NF-кB nuclear translocation through inhibiting the phosphorylation of $\mathrm{I} \kappa \mathrm{B}$.

Anti-oxidative activity has been reported to be linked to anti-inflammatory activity (23). Therefore, we investigated the anti-oxidative activity of curcumin, tetrahydrocurcumin and monoacetylcurcumin against the ROS production induced by TNF- $\alpha$ (Fig. 2D). In HEK293 cells, $50 \mu \mathrm{M}$ curcumin, tetrahydrocurcumin or monoacetylcurcumin decreased the $50 \mathrm{ng} / \mathrm{ml}$ TNF- $\alpha$-induced ROS production to $60.7,39.4$ and $32.1 \%$, respectively. These results suggest that curcumin, tetrahydrocurcumin and monoacetylcurcumin possess antioxidative activity.

The inhibitory activity of curcumin and curcumin derivatives against LPS-induced inflammation in vivo. To assess their anti-inflammatory effects in vivo, we investigated the 
A

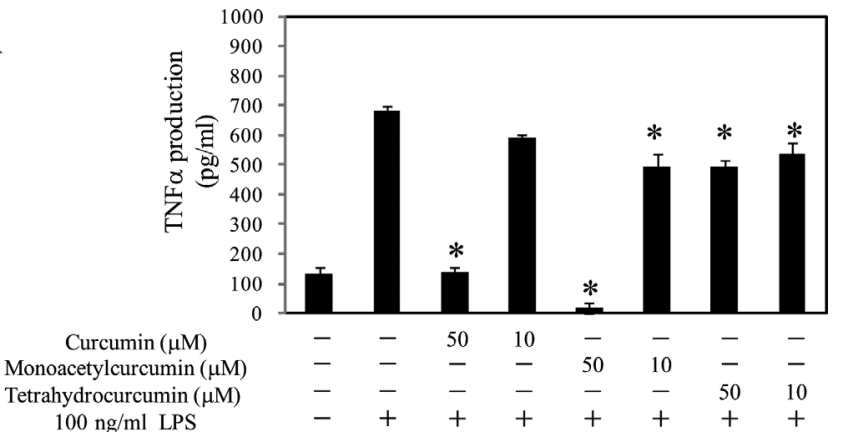

B

a)

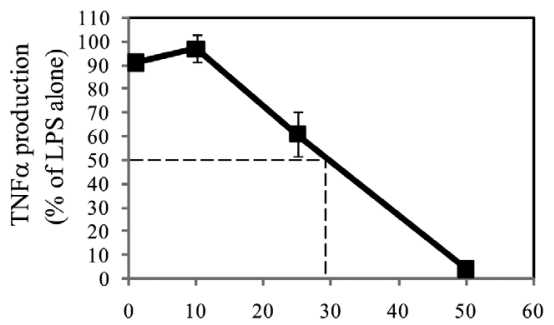

b)

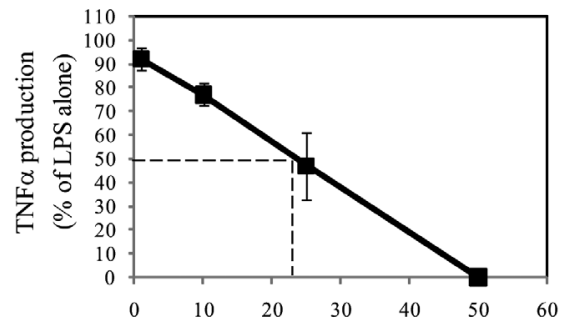

c)

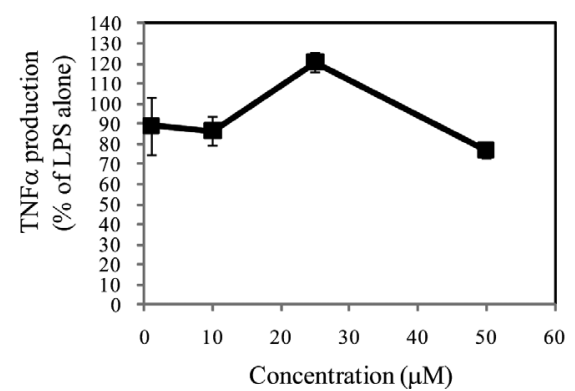

C

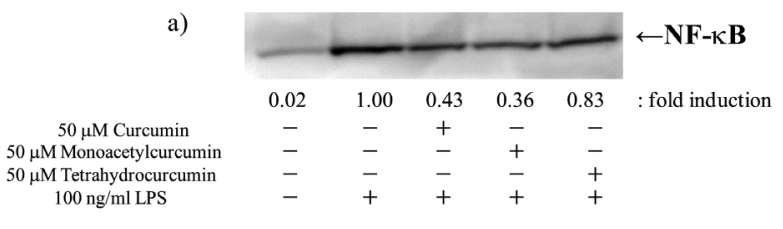

b)

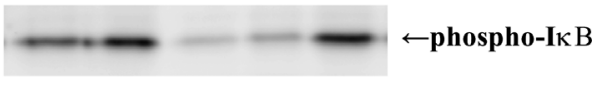

$\begin{array}{llllll}0.62 & 1.00 & 0.40 & 0.44 & 0.80 & \text { : fold induction }\end{array}$

$50 \mu \mathrm{M}$ Curcumin $50 \mu \mathrm{M}$ Monoacetylcurcumin $50 \mu \mathrm{M}$ Tetrahydrocurcumin $20 \mathrm{ng} / \mathrm{ml}$ TNF- $\alpha$

c)

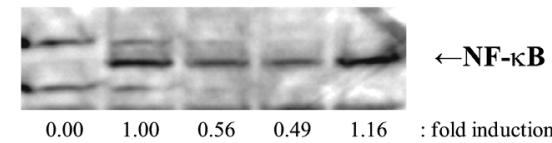

$50 \mu \mathrm{M}$ Curcumin $50 \mu \mathrm{M}$ Monoacetylcurcumin $20 \mathrm{ng} / \mathrm{ml}$ TNF- $\alpha$

$\begin{array}{lllll}- & - & + & - & - \\ - & - & - & + & - \\ - & - & - & - & + \\ - & + & + & + & +\end{array}$

D

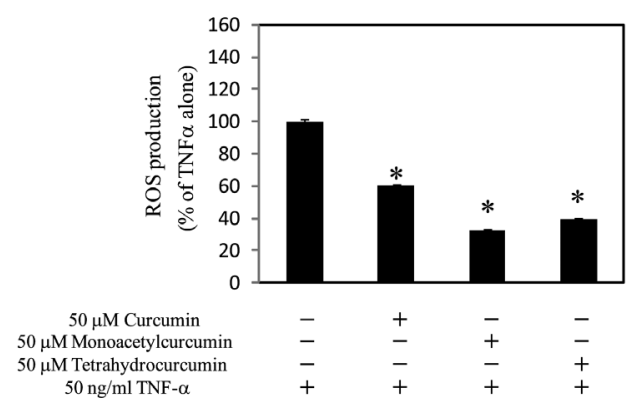

Figure 2. The inhibitory activities of curcumin and curcumin derivatives against inflammatory responses in cultured cells. (A) RAW264.7 cells were pretreated with 10 or $50 \mu \mathrm{M}$ curcumin, tetrahydrocurcumin or monoacetylcurcumin for $30 \mathrm{~min}$ and then incubated with $100 \mathrm{ng} / \mathrm{ml} \mathrm{LPS} \mathrm{for} 24 \mathrm{~h}$. The TNF- $\alpha$ level in the culture medium was measured using ELISA. Data are shown as the mean \pm SE $(n=4)$. "Significant difference according to the Student's t-test $(\mathrm{p}<0.05)$. (B) RAW264.7 cells were pretreated with curcumin (a), tetrahydrocurcumin (b) or monoacetylcurcumin (c) at the indicated concentrations for 30 min and subsequently incubated with $100 \mathrm{ng} / \mathrm{ml}$ LPS for $24 \mathrm{~h}$. The TNF- $\alpha$ level in the culture medium was measured using ELISA. Data are shown as a percentage of the $100 \mathrm{ng} / \mathrm{ml}$ LPS-induced TNF- $\alpha$ production, and values are represented as the means \pm SE $(n=4)$. (C) RAW264.7 cells were pretreated with $50 \mu \mathrm{M}$ curcumin, tetrahydrocurcumin or monoacetylcurcumin, followed by incubation with $100 \mathrm{ng} / \mathrm{ml}$ LPS for 30 min. The nuclear translocation of NF- $\mathrm{B}$ p65 (a) and the phosphorylation of IкB (b) were evaluated by Western blot analysis as described in Materials and methods. The intensity of each band was analyzed, and the values relative to treatment with LPS alone are represented at the lower edge of the image. HEK293 cells were pretreated with $50 \mu \mathrm{M}$ curcumin, tetrahydrocurcumin, or monoacetylcurcumin for $30 \mathrm{~min}$, and then treated with $20 \mathrm{ng} / \mathrm{ml} \mathrm{TNF- \alpha}$ for $30 \mathrm{~min}$. The nuclear translocation of NF-kB p65 (c) was evaluated by Western blot analysis as described in Materials and methods. The intensity of each band was analyzed, and the values relative to treatment with TNF- $\alpha$ alone are represented at the lower edge of the image. (D) HEK293 cells were pretreated with $50 \mu \mathrm{M}$ curcumin, tetrahydrocurcumin or mono-acetylcurcumin for $30 \mathrm{~min}$, followed by treatment with $50 \mathrm{ng} / \mathrm{ml} \mathrm{TNF}-\alpha$ and $4 \mu \mathrm{M}$ DCFH-DA for 30 min. The fluorescent intensity of DCF was measured as described in Materials and methods. Data is shown as the mean $\pm \mathrm{SE}(\mathrm{n}=4)$. " Significant differences according to the Student's t-test $(\mathrm{p}<0.05)$.

inhibitory activity of curcumin, tetrahydrocurcumin and monoacetylcurcumin against LPS-induced acute inflammation (Fig. 3). Treatment with $250 \mu \mathrm{g} / \mathrm{kg}$ BW LPS significantly increased the serum TNF- $\alpha$ level, and an oral injection of $100 \mathrm{mg} / \mathrm{kg} \mathrm{BW}$ monoacetylcurcumin decreased the LPSinduced TNF- $\alpha$ production to $36 \%$. Curcumin and tetra- hydrocurcumin had no effect. Next, the inhibitory effects of curcumin, tetrahydrocurcumin and monoacetylcurcumin on $\mathrm{NF}-\mathrm{kB}$ nuclear translocation in the liver were examined. We found that LPS caused the translocation of NF- $\mathrm{KB}$ into the nucleus, and monoacetylcurcumin blocked the nuclear translocation, although tetrahydrocurcumin did not have an 
A

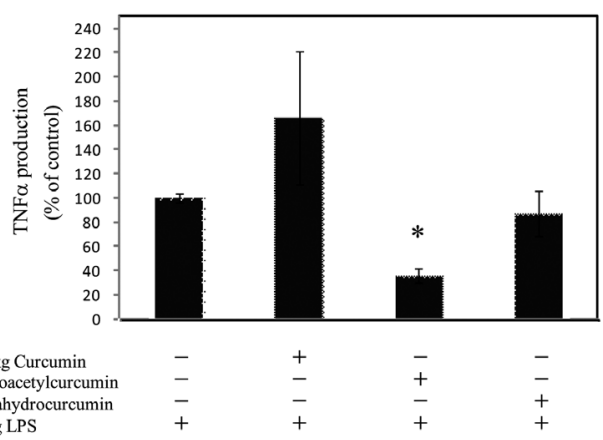

B

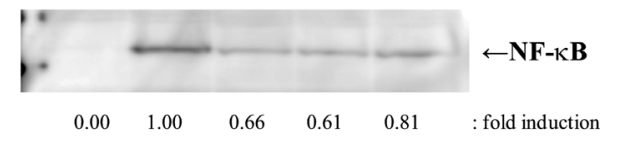

$100 \mathrm{mg} / \mathrm{kg}$ Curcumin

mg/kg Monoacetylcurcumi

$250 \mu \mathrm{g} / \mathrm{kg}$ LPS

\section{: fold induction}

\begin{abstract}
$100 \mathrm{mg} / \mathrm{kg}$ Curcumin
$100 \mathrm{mg} / \mathrm{kg}$ Monoacetylcurcumi $00 \mathrm{mg} / \mathrm{kg}$ Tetrahydrocurcumin $250 \mu \mathrm{g} / \mathrm{kg} \mathrm{LPS}$
\end{abstract}

Figure 3. The inhibitory activities of curcumin and curcumin derivatives against LPS-induced inflammation in vivo. Male C57BL/6 mice were orally administered curcumin, tetrahydrocurcumin, or monoacetylcurcumin at $100 \mathrm{mg} / \mathrm{kg} \mathrm{BW}$ or corn oil as a vehicle control. After $2 \mathrm{~h}$, the mice were intraperitoneally injected with LPS at $250 \mu \mathrm{g} / \mathrm{kg} \mathrm{BW}$ or saline as a vehicle control. One hour after the LPS injection, the mice were sacrificed. (A) The TNF- $\alpha$ level in serum was measured using ELISA. Data are shown as the mean \pm SE $(n=4)$. *Significant difference according to the Student's t-test $(\mathrm{p}<0.05)$. The treatment with corn oil and LPS (positive control) is shown as $100 \%$ (TNF- $\alpha$ level, $728 \mathrm{pg} / \mathrm{ml}$ ) and that with corn oil and saline (negative control) is shown as $0 \%$ (TNF- $\alpha$ level, $32 \mathrm{pg} / \mathrm{ml}$ ). (B) NF-кB p65 in the nuclei of mouse liver cells was detected by Western blotting as described in Materials and methods. The intensity of each band was analyzed, and the values relative to treatment with LPS alone are represented at the lower edge of the image.

inhibitory effect. Notably, curcumin inhibited NF-кB nuclear translocation although it did not block TNF- $\alpha$ production.

\section{Discussion}

Numerous studies have demonstrated that curcumin has various biological activities. The anti-inflammatory activity of curcumin is one such biological activity, and it has been reported that curcumin exerts its anti-inflammatory effect through the inhibition of NF- $\mathrm{KB}$ nuclear translocation (24). In agreement with a previous study, our results showed that curcumin was able to inhibit the NF-кB nuclear translocation induced by LPS and TNF- $\alpha$ (Fig. 2C) in an in vitro cell culture experiment. In this study, we examined the inhibitory effects of curcumin derivatives against the inflammatory responses in the hope that they possess stronger effects than curcumin. Our previous study found that curcumin is a specific DNA polymerase $\lambda$ inhibitor of the 10 mammalian DNA polymerase species (16), and the inhibitory effect of monoacetylcurcumin on DNA polymerase $\lambda$ activity was the strongest among the 13 chemically synthesized curcumin derivatives including curcumin (17). However, the antiinflammatory activity of monoacetylcurcumin is still unknown. Therefore, we investigated the suppressive effects of monoacetylcurcumin against the LPS-evoked inflammatory responses in vitro and in vivo. Our results revealed that monoacetylcurcumin inhibited $\mathrm{NF}-\kappa \mathrm{B}$ nuclear translocation in the in vitro-cell culture systems (Fig. 2C) and in vivo (Fig. 3). We also found that monoacetylcurcumin suppressed the LPS-induced phosphorylation of IкB in RAW264.7 cells. In addition, monoacetylcurcumin suppressed the LPSinduced increase in the serum TNF- $\alpha$ level, although curcumin had no effect (Fig. 3A). The differences in the actions of curcumin, tetrahydrocurcumin and monoacetylcurcumin in in vivo experiments may involve their bioavailability. Therefore, the serum levels of curcumin, tetrahydrocurcumin and monoacetylcurcumin $2 \mathrm{~h}$ after their oral administration were measured by a liquid chromatography mass spectrometer. Their serum concentrations were below the detection limit and were $<0.3 \mathrm{nM}$ for curcumin and monoacetylcurcumin, and $3 \mathrm{nM}$ for tetrahydrocurcumin (data not shown). It has been reported that curcumin is difficult to be absorbed into the body (10). A lower level of monoacetylcurcumin than curcumin and tetrahydrocurcumin might be able to decrease the serum TNF- $\alpha$ level in mice treated with LPS.

Sandur et al investigated the anti-inflammatory effects of curcumin and curcumin analogues, such as emethoxycurcumin (DMC) and bisdemethoxycurcumin (BDMC), and the order of their suppressive effects on TNF- $\alpha$-induced NF-кB activation was found to be curcumin $>$ DMC $>$ BDMC (15). Curcumin possesses two phenyl methoxy groups and DMC possesses one. BDMC does not have any phenyl methoxy groups. Therefore, it was suggested that the functional groups on the phenyl ring play a critical role in the inhibition of NF- $\mathrm{KB}$ activation. Monoacetylcurcumin and curcumin include two phenyl methoxy groups, and one of the phenyl methoxy groups of monoacetylcurcumin possesses an acetyl group (Fig. 1). We showed that monoacetylcurcumin strongly inhibited the LPS- and TNF- $\alpha$-stimulated NF- $\kappa$ B activation (Fig. 2C). Notably, monoacetylcurcumin inhibited the LPSinduced increase in the serum TNF- $\alpha$ level in vivo, although curcumin did not exhibit an effect (Fig. 3A). Therefore, we propose that the acetyl group on the phenyl ring is also involved in stronger suppression of NF- $\mathrm{B}$ nuclear translocation and inflammatory responses, although the only difference in chemical structure between monoacetylcurcumin and curcumin lies in the presence or absence of the acetyl group on the phenyl ring (Fig. 1). Furthermore, our study demonstrated that conjugated bonds in the central seven-carbon chain are important for the suppression of NF-кB nuclear translocation and the subsequent inflammatory responses, since tetrahydrocurcumin did not exert a suppressive effect on inflammation (Fig. 2A-C), and the only difference in chemical structure between curcumin and tetrahydrocurcumin is in several of the conjugated bonds of the central seven-carbon chain (Fig. 1).

In this study, we found that, not only curcumin and tetrahydrocurcumin, but also monoacetylcurcumin have antioxidative activity against TNF- $\alpha$-induced ROS production and that the order of anti-oxidative ability is monoacetylcurcumin $>$ tetrahydrocurcumin $>$ curcumin (Fig. 2D). A previous study demonstrated that curcumin derivatives regulate inflammatory responses through a ROS-independent mechanism (15). In fact, our results indicate that the antioxidative effects of curcumin and curcumin derivatives are 
independent of their inhibitory activity against TNF- $\alpha$ production since tetrahydrocurcumin had no anti-inflammatory effect (Figs. 2A-C and 3) despite its high anti-oxidative activity (Fig. 2D). These results indicate that the active site(s) of curcumin and curcumin derivatives for inhibition of TNF- $\alpha$ production are different than those for anti-oxidative activity. Previous studies have indicated that the active sites of curcumin and tetrahydrocurcumin related to their antioxidative activity are composed of hydroxy and carbonyl groups located in the centers of their chemical structures (15). Furthermore, it has been reported that curcuminoids inhibit T-lymphocyte proliferation independently of their radical scavenging activity; the inhibitory effects were dependent on the number of carbon atoms and doubles of the 1,6-heptadiene-3,5-dione structure as well as on the phenolic ring substitutes of the curcuminoids, and were not correlated to their respective radical scavenging activity (25). Curcumin, tetrahydrocurcumin and monoacetylcurcumin all include hydroxy plus carbonyl groups (Fig. 1). Monoacetylcurcumin exhibited high inhibitory activity against TNF- $\alpha$ production (Figs. 2 and 3 ) and anti-oxidative activity (Fig. 2D). Therefore, the acetyl group of monoacetylcurcumin may enhance its anti-oxidative activity using a part of its hydroxy plus carbonyl group.

In conclusion, we found that monoacetylcurcumin, which includes an acetyl group on its phenyl ring, regulates the inflammatory responses by inhibiting $\mathrm{I} \kappa \mathrm{B}$ phosphorylation and NF- $\mathrm{BB}$ nuclear translocation, and the effects of monoacetylcurcumin are more potent than those of curcumin and tetrahydrocurcumin. Our study is the first to demonstrate that monoacetylcurcumin reduces $\mathrm{NF}-\kappa \mathrm{B}$ activation and $\mathrm{TNF}-\alpha$ production. We also suggest the importance of the acetyl group on the phenyl ring in the suppression of inflammatory responses by monoacetylcurcumin. In a previous study, monoacetylcurcumin was reported to exert anti-inflammatory activity in a $O$-tetradecanoylphorbol-13-acetate-induced ear edema model although its molecular mechanism is yet unknown (26). Since the activated NF- $\mathrm{KB}$ was observed in a 12-O-tetradecanoylphorbol-13-acetate-induced ear edema model (27), its anti-inflammatory effects may be at least in part dependent on the inhibition of $N F-\kappa B$ activation. At present, curcumin is regarded as a promising chemopreventive agent against inflammatory responses. Our study indicates that monoacetylcurcumin is useful as an NF- $\mathrm{B}$ inhibitor and may be a potent chemopreventive agent against inflammation.

\section{Acknowledgements}

This work was supported, in part, by a grant for the Global COE Program 'Global Center of Excellence for Education and Research on Signal Transduction Medicine in the Coming Generation' from the Ministry of Education, Culture, Sports, Science, and Technology of Japan. Tetrahydrocurcumin was kindly provided by Dr Osawa of the Laboratory of Food and Biodynamics, Graduate School of Bioagricultural Science, Nagoya University. Monoacetylcurcumin was kindly provided by the research group of Dr Sugawara of the Department of Applied Biological Science, Tokyo University of Science.

\section{References}

1. Biswas $\mathrm{S}$ and Rahman I: Modulation of steroid activity in chronic inflammation: a novel anti-inflammatory role for curcumin. Mol Nutr Food Res 52: 987-994, 2008.

2. Shakibaei M and John T: Suppression of $\mathrm{NF}_{-\kappa \mathrm{B}}$ activation by curcumin leads to inhibition of expression of cyclooxygenase-2 and matrix metalloproteinase-9 in human articular chondrocytes: Implications for the treatment of osteoarthritis. Biochem Pharmacol 73: 1434-1445, 2007.

3. Huang TT and Wuerzberger-Davis SM: Sequential modification of NEMO/IKK $\gamma$ by SUMO-1 and ubiquitin mediates NF- $\kappa$ B activation by genotoxic stress. Cell 115: 565-576, 2003.

4. Hayden MS and Ghosh S: Signaling to NF-кB. Genes Dev 18: 2195-2224, 2004

5. Bonizzi G and Karin M: The two NF-kappaB activation pathways and their role in innate and adaptive immunity. Trends Immunol 25: 280-288, 2004.

6. Wajant H, Pfizenmaier K and Scheurich P: Tumor necrosis factor signaling. Cell Death Differ 10: 45-65, 2003.

7. Elson CO, Sartor RB, Tennyson GS and Riddell RH: Experimental models of inflammatory bowel disease. Gastroenterology 109: 1344-1367, 1995.

8. Sugimoto K, Hanai H, Tozawa K, Aoshi T, Uchijima M, Nagata T and Koide Y: Curcumin prevents and ameliorates trinitrobenzene sulfonic acid-induced colitis in mice. Gastroenterology 123: 1912-1922, 2002.

9. Asai A and Miyazawa T: Occurrence of orally administered curcuminoids as glucuronide and glucuronide/sulfate conjugates in rat plasma. Life Sci 67: 2785-2793, 2000.

10. Anand P, Kunnumakkara AB, Newman RA and Aggarwal BB: Bioavailability of curcumin: problems and promises. Mol Pharm 4: 807-818, 2007.

11. Pan MH, Huang TM and Lin JK: Biotransformation of curcumin through reduction and glucuronidation in mice. Drug Metab Dispos 27: 486-494, 1999.

12. Osawa T and Kato Y: Protective role of antioxidative food factors in oxidative stress caused by hyperglycemia. Ann NY Acad Sci 1043: 440-451, 2005

13. Pari L and Amali DR: Protective role of tetrahydrocurcumin (THC) an active principle of turmeric on chloroquine induced hepatotoxicity in rat. J Pharm Sci 8: 115-123, 2005.

14. Limtrakul P, Chearwae W, Shukla S, Phisalphong C and Ambudkar SV: Modulation of function of three ABC drug transporters, $\mathrm{P}$ glycoprotein (ABCB1), mitoxantrone resistance protein $(\mathrm{ABCG} 2)$ and multidrug resistance protein 1 (ABCC1) by tetrahydrocurcumin, a major metabolite of curcumin. Mol Cell Biochem 296: 85-95, 2007.

15. Sandur SK, Pandey MK, Sung B, et al: Curcumin, demethoxycurcumin, bisdemethoxycurcumin, tetrahydrocurcumin and turmerones differentially regulate antiinflammatory and anti-proliferative responses through a ROSindependent mechanism. Carcinogenesis 28: 1765-1773, 2007.

16. Mizushina Y, Hirota M, Murakami C, et al: Some anti-chronic inflammatory compounds are DNA polymerase lambda-specific inhibitors. Biochem Pharmacol 66: 1935-1944, 2003.

17. Takeuchi $\mathrm{T}$, Ishidoh $\mathrm{T}$, Iijima $\mathrm{H}$, et al: Structural relationship of curcumin derivatives binding to the BRCT domain of human DNA polymerase lambda. Genes Cells 11: 223-235, 2006.

18. Sugiyama Y, Kawakishi $\mathrm{S}$ and Osawa T: Involvement of the beta-diketone moiety in the antioxidative mechanism of tetrahydrocurcumin. Biochem Pharmacol 52: 519-525, 1996.

19. Nishiumi S, Yamamoto N, Kodoi R, Fukuda I, Yoshida K and Ashida H: Antagonistic and agonistic effects of indigoids on the transformation of an aryl hydrocarbon receptor. Arch Biochem Biophys 470: 187-199, 2008.

20. Corda S, Laplace C, Vicaut E and Duranteau J: Rapid reactive oxygen species production by mitochondria in endothelial cells exposed to tumor necrosis factor-alpha is mediated by ceramide. Am J Respir Cell Mol Biol 24: 762-768, 2001.

21. Li Q and Verma IM: NF-кB regulation in the immune system. Nat Rev Immunol 2: 725-734, 2002.

22. Hashimoto T, Nonaka Y, Minato K, et al: Suppressive effect of polysaccharides from the edible and medicinal mushrooms, Lentinus edodes and Agaricus blazei, on the expression of cytochrome P450s in mice. Biosci Biotechnol Biochem 66: 1610-1614, 2002.

23. Rahman I, Biswas SK and Kirkham PA: Regulation of inflammation and redox signaling by dietary polyphenols. Biochem Pharmacol 72: 1439-1452, 2006. 
24. Kim GY, Kim KH, Lee SH, et al: Curcumin inhibits immunostimulatory function of dendritic cells: MAPKs and translocation of NF-kappa B as potential targets. J Immunol 174: 8116-8124, 2005.

25. Deters M, Knochenwefel H, Lindhorst D, et al: Different curcuminoids inhibit T-lymphocyte proliferation independently of their radical scavenging activities. Pharm Res 8: 1822-1827, 2008.

26. Mizushina Y, Takeuchi T, Kuramochi K, et al: Study on the molecular structure and bio-activity (DNA polymerase inhibitory activity, anti-inflammatory activity and anti-oxidant activity) relationship of curcumin derivatives. Curr Bioactive Compounds 3: 171-177, 2007.
27. Medeiros R, Otuki MF, Avellar MC and Calixto JB: Mechanisms underlying the inhibitory actions of the pentacyclic triterpene alpha-amyrin in the mouse skin inflammation induced by phorbol ester 12-O-tetradecanoylphorbol-13-acetate. Eur J Pharmacol 559: 227-235, 2007. 